\title{
INVESTIGATION OF GLUCURONIC ACID METABOLISM IN HUMAN SUBJECTS ${ }^{1,2}$
}

\author{
BY W. H. FISHMAN, M. SMITH, D. B. THOMPSON, C. D. BONNER, S. C. KASDON, \\ AND F. HOMBURGER \\ (From the Cancer Research and Control Unit of the Department of Surgery, Departments of \\ Medicine and Biochemistry, Tufts College Medical School, Boston, Mass. and the \\ Research Laboratory of the Jewish Memorial Hospital, Roxbury, Mass.)
}

(Submitted for publication December 13, 1950; accepted April 9, 1951)

Recent interest in the metabolism of glucuronic acid has been aroused mainly as a result of the realization (1) that the conjugation of glucuronic acid is an important step in the metabolism of estrogenic and steroid hormones $(2,3)$ and of epinephrine (4) and following the reports that glucuronic acid may be useful in arthritis (5). Although the mechanism of formation of glucuronides has been observed chiefly in studies of drug metabolism and has been widely accepted as a process of detoxication, the view is now prevalent $(6,7,8)$ that this reaction represents a physiological process which we consider a "metabolic conjugation" (1). Thus, it is believed that exogenous drugs are conjugated with glucuronic acid only by virtue of certain of their chemical groupings (phenolic or alcoholic hydroxyl radicals), characteristic of the endogenous metabolites which are physiologically conjugated with glucuronic acid.

In the past, studies on glucuronic acid metabolism have been carried out almost exclusively in animals and usually in these investigations the conjugated glucuronide was isolated or determinations of urinary glucuronic acid were made (9). It is obvious that determinations of glucuronic acid in blood values would be of great value not only in animal studies but also in investigations performed in man. Accordingly, a combination of blood and urine data on glucuronic acid was considered to be necessary in any study designed to evaluate the physiological significance of glucuronic acid.

The present paper is divided into three sections. The first deals with the description of the method

1 This work was supported by grants-in-aid from the National Cancer Institute, Bethesda, Maryland, the Damon Runyon Memorial Fund for Cancer Research, the Commercial Solvents Corporation, New York, and by an institutional grant of the American Cancer Society, Inc., New York.

2 Presented in part at the 119th annual meeting of the American Chemical Society, April 1, 1951, Boston, Mass. for determining glucuronic acid and its clinical application. The second concerns the development of a glucuronic acid tolerance test in humans, and the third describes some clinical observations relating glucuronic acid and $\beta$-glucuronidase to arthritis and cancer of the breast.

\section{SECTION I. DETERMINATION OF GLU- CURONIC ACID IN BLOOD AND URINE}

The available methods for determining blood glucuronic acid were found to be unsuited for the purpose which we had in mind, i.e., the performance of as many as 100 determinations a day with reasonable accuracy. In 1943, Ratish and Bullowa (10) adapted the method of Maughan, Evelyn and Browne (11) for urinary glucuronic acid to the determination of glucuronic acid ${ }^{3}$ in blood. An aliquot of a tungstic acid filtrate of blood was heated with a mixture of naphthoresorcinol and hydrochloric acid for 45 minutes. After cooling, the violet pigment was extracted, using a mixture of alcohol and ether, and the optical density of the ether layer read at $565 \mathrm{~m} \mu$ in a photoelectric colorimeter. The per cent error ranged from -11 to + 21.2. The procedure of Deichmann (12) in 1946 was performed on plasma (without deproteinization) with the naphthoresorcinol reagent, utilizing a heating period of two hours and extraction of the pigment with ether alone. Although as a rule satisfactory recoveries of glucuronic acid were obtained when it was added to plasma, frequently these were as low as 20 to 30 per cent. The use of

3 The possibility tuat the naphthoresorcinol reaction may measure galacturonic acid as well as glucuronic acid has been pointed out by Deichrann and Dierker (12). However, in view of the fact that galacturonic acid has not yet been identified as a normal constituent of human blood and urine, it is permissible to consider the naphthoresorcinol reaction applied to protein-free filtrates of blood as one measuring essentially glucuronic acid. 
ether in these procedures has the following disadvantages : rapid evaporation, especially in the summer, a strict requirement of purification and dehydration $(10,11)$, instability upon exposure to sunlight (12), and the presence of a serious fire hazard.

It was found possible to combine the best features of the available methods and to substitute toluene for ether as the solvent for extracting the colored product of the naphthoresorcinol-glucuronic acid reaction. In this manner, a procedure has been developed which is reasonably accurate and reliable, and possesses the advantage of convenience and safety.

\section{REAGENTS REQUIRED}

10 per cent sodium tungstate solution

$0.66 \mathrm{~N}$ sulfuric acid solution

0.2 per cent naphthoresorcinol solution. (A fresh solution was made for each day's determinations, employing the product obtained from Schwartz Laboratories, Inc., New York. Shaking the naphthoresorcinol water mixture in a glass-stoppered cylinder for 10 minutes effected solution.)

Toluene, Merck C. P.

Hydrochloric acid, concentrated, Merck C. P.

\section{METHOD OF ANALYSIS}

(a) Blood. Two cc. of well-mixed oxalated blood were pipetted slowly into $14 \mathrm{cc}$. of distilled water in an Erlenmeyer flask, the contents being shaken during the process. Then, 2 cc. each of 10 per cent sodium tungstate and 0.66 $\mathrm{N}_{2} \mathrm{SO}_{4}$ were added and the whole mixture agitated to ensure complete mixing. After 10 minutes it was filtered. Three cc. quantities of this filtrate representing a 1 to 10 dilution of the blood, were transferred to two duplicate boiling tubes, ${ }^{4}$ of the dimensions of the ordinary N.P. N. boiling tubes, but fitted with ground glass stoppers. To these were added $2 \mathrm{cc}$. of 0.2 per cent naphthoresorcinol solution and $2 \mathrm{cc}$. of concentrated hydrochloric acid solution. The contents of the tube were mixed well and glass stoppers inserted. These tubes, arranged in a suitable metal rack, were placed in a gently boiling steam-heated water bath (temperature $98^{\circ} \mathrm{C}$ ) for 60 minutes. They were then immersed in cold water (temperature $+5^{\circ} \mathrm{C}$ )

4 These may be purchased from Macalaster Bicknell Co., Cambridge, Mass. The following washing procedure was found necessary: the tubes were rinsed thoroughly after the analysis with alcohol and tap water before being placed in cleaning solution. The use of a wax pencil for marking these tubes is prohibited, since any wax which finds its way into the boiling tubes will dissolve in the toluene and give undesirable colored solutions. Marking with a lead pencil on a ground glass spot on these tubes is permissible. for 10-15 minutes. After cooling, $5 \mathrm{cc}$. of 95 per cent alcohol were added to each tube, after which they were shaken to dissolve the pigment produced during the heating reaction. Then, $8 \mathrm{cc}$. of toluene were added and the tubes restoppered and vigorously shaken for one minute, this time to extract the violet pigment into the toluene phase. The aqueous layer was removed completely by suction, using a tube drawn out to a capillary attached to an aspirator and a collecting bottle. The toluene extracts were then transferred carefully to clean Evelyn cuvettes. After allowing them to stand 45 minutes in the dark to permit the extracts to clear, the transmission of light was measured in the Evelyn photoelectric colorimeter at $565 \mathrm{~m} \mu$ using the $6 \mathrm{cc}$. well.

(b) Urine. Usually a 1 to 50 dilution of the urine was prepared with water. In urine rich in glucuronic acid a 1 to 100 dilution was employed. The deproteinization procedure was omitted, and the naphthoresorcinol and $\mathrm{HCl}$

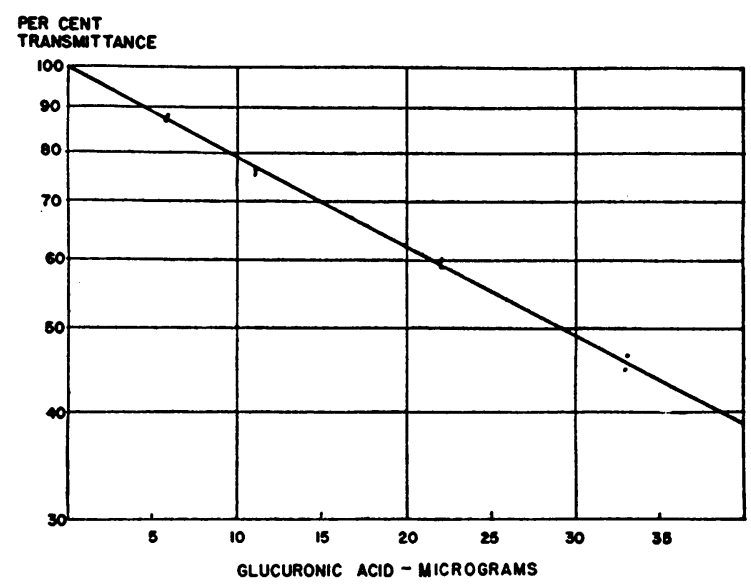

Fig. 1. Relationship Between the Light Transmittance of the Glucuronic Acid-Naphthoresorcinol Reaction Product and Glucuronic Acid ConcentraTION

solutions were added directly to $3 \mathrm{cc}$. of diluted urine. Readings in the colorimeter were made in the same way as for blood.

Blanks and controls. Blanks contained $3 \mathrm{cc}$. of $\mathrm{H}_{2} \mathrm{O}$ in place of blood filtrate or urine. It is desirable to include a standard ( $20 \gamma$ glucuronic acid) with each day's determinations. The optical density of this standard should read within 5 per cent of the expected optical density.

Preparation of standard curve. This (Figure 1) was constructed by correlating per cent transmittance with the content of glucuronolactone expressed as glucuronic acid in the standard solutions. It was found that the standard curve was completely reproducible. A curve should be constructed whenever new reagents (e.g., concentrated $\mathrm{HCl}$ or naphthoresorcinol) are employed.

Calculation of results. The amount of glucuronic acid obtained by substituting the Evelyn reading of the unknown into the standard curve is termed $\gamma \mathrm{G}$. A. The following 
expressions apply then to blood and urine:

Blood: $\frac{\gamma \text { G. A. } \times 10 \times 100}{3 \times 1000}=$ milligrams glucuronic acid per $100 \mathrm{cc}$.

Urine : $\frac{\gamma \text { G. A. } \times 50}{3 \times 1000}=$ milligrams glucuronic acid per cc. urine, when 50 is the dilution factor of the urine.

Light absorption curves of the naphthoresorcinol reaction product. Curves (Figure 2 ) for proteinfree filtrates of human blood, urine, and a sample

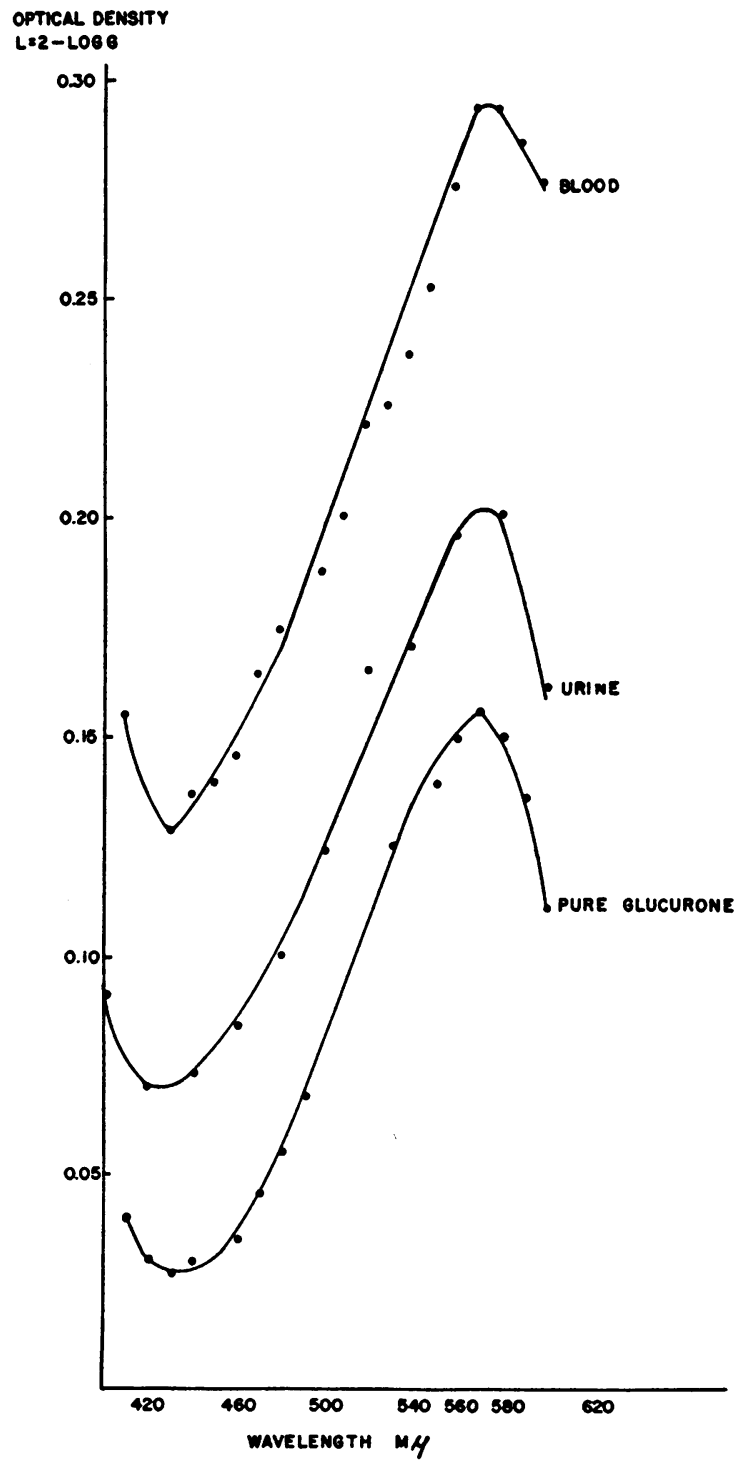

Fig. 2. Light Absorption Curves of the Toluene Solutions of the Glucuronic Acid-Naphthoresorcinol Product Obtained from Pure Glucurone (20 $\gamma$ ), a Protein-Free Blood Filtrate $(49 \gamma)$, and Urine, Diluted 1 то $50(30 \gamma)$
TABLE I

Recovery of glucuronic acid added to blood and urine

\begin{tabular}{|c|c|c|c|c|}
\hline \multirow{2}{*}{$\begin{array}{c}\text { Experiment } \\
\text { number }\end{array}$} & \multirow{2}{*}{$\begin{array}{l}\text { Glucuronic } \\
\text { acid }\end{array}$} & \multirow{2}{*}{$\begin{array}{l}\text { Glucuronic } \\
\text { acid added }\end{array}$} & \multicolumn{2}{|c|}{ Total glucuronic acid } \\
\hline & & & Found & Calculated \\
\hline $\begin{array}{r}\text { Blood } \\
1 .\end{array}$ & $\begin{array}{c}m g . / 100 \text { cc. } \\
5.4 \\
5.4\end{array}$ & $\begin{array}{c}m g . / 100 c c . \\
3.5 \\
7.0\end{array}$ & $\begin{array}{c}m . / 100 c c . \\
9.6 \\
11.2\end{array}$ & $\begin{array}{c}\text { mg./100 cc. } \\
8.9 \\
12.4\end{array}$ \\
\hline 2. & $\begin{array}{l}6.2 \\
6.2\end{array}$ & $\begin{array}{l}3.5 \\
7.0\end{array}$ & $\begin{array}{r}9.5 \\
13.0\end{array}$ & $\begin{array}{r}9.7 \\
13.2\end{array}$ \\
\hline 3. & $\begin{array}{l}6.0 \\
6.0\end{array}$ & $\begin{array}{l}3.5 \\
7.0\end{array}$ & $\begin{array}{r}8.3 \\
10.8\end{array}$ & $\begin{array}{r}9.5 \\
13.0\end{array}$ \\
\hline 4. & $\begin{array}{l}7.6 \\
7.6\end{array}$ & $\begin{array}{l}3.5 \\
7.0\end{array}$ & $\begin{array}{l}10.8 \\
14.2\end{array}$ & $\begin{array}{l}11.1 \\
14.6\end{array}$ \\
\hline 5. & $\begin{array}{l}6.7 \\
6.7\end{array}$ & $\begin{array}{l}3.5 \\
7.0\end{array}$ & $\begin{array}{l}10.0 \\
12.3\end{array}$ & $\begin{array}{l}10.2 \\
13.7\end{array}$ \\
\hline $\begin{array}{r}\text { Urine } \\
1 .\end{array}$ & $\begin{array}{l}30.4 \\
30.4\end{array}$ & $\begin{array}{r}8.4 \\
16.8\end{array}$ & $\begin{array}{l}36.4 \\
49.5\end{array}$ & $\begin{array}{l}38.8 \\
47.2\end{array}$ \\
\hline 2. & $\begin{array}{l}54.0 \\
54.0\end{array}$ & $\begin{array}{r}8.4 \\
16.8\end{array}$ & $\begin{array}{l}61.6 \\
79.1\end{array}$ & $\begin{array}{l}62.4 \\
70.8\end{array}$ \\
\hline 3. & $\begin{array}{l}37.6 \\
37.6\end{array}$ & $\begin{array}{r}8.4 \\
16.8\end{array}$ & $\begin{array}{l}45.0 \\
50.8\end{array}$ & $\begin{array}{l}46.0 \\
54.4\end{array}$ \\
\hline 4. & $\begin{array}{l}54.1 \\
54.1\end{array}$ & $\begin{array}{r}8.4 \\
16.8\end{array}$ & $\begin{array}{l}58.3 \\
68.0\end{array}$ & $\begin{array}{l}62.5 \\
70.9\end{array}$ \\
\hline 5. & $\begin{array}{l}45.2 \\
45.2\end{array}$ & $\begin{array}{r}8.4 \\
16.8\end{array}$ & $\begin{array}{l}49.5 \\
60.6\end{array}$ & $\begin{array}{l}53.6 \\
62.0\end{array}$ \\
\hline 6. & $\begin{array}{l}36.6 \\
34.1 \\
56.7\end{array}$ & $\begin{array}{l}16.8 \\
16.8 \\
16.8\end{array}$ & $\begin{array}{l}48.3 \\
46.3 \\
70.0\end{array}$ & $\begin{array}{l}53.4 \\
50.9 \\
73.5\end{array}$ \\
\hline
\end{tabular}

of pure glucuronolactone are shown in which the light absorption of the purple toluene layer was measured in a Beckman model B spectrophotometer over the range $400-600 \mathrm{~m} \mu$.

Recovery of glucuronic acid added to blood and urine. In Table I are listed the recoveries of pure glucuronic acid added to whole blood and urine. In the upper range of blood glucuronic acid levels (8.9-11.1), the standard error was 7.3 per cent (range -7 to +14 ) and for all the recovery experiments, the standard error was 8 per cent (range -20 to +14$)$. This performance of the method is similar to that of the method of Ratish and Bullowa (10).

Distribution of blood glucuronic acid values in health and in some disease states. In Figure 3 is illustrated the distribution of blood glucuronic acid in 100 normal individuals and in two groups of patients, one with arthritis and the other with cancer 


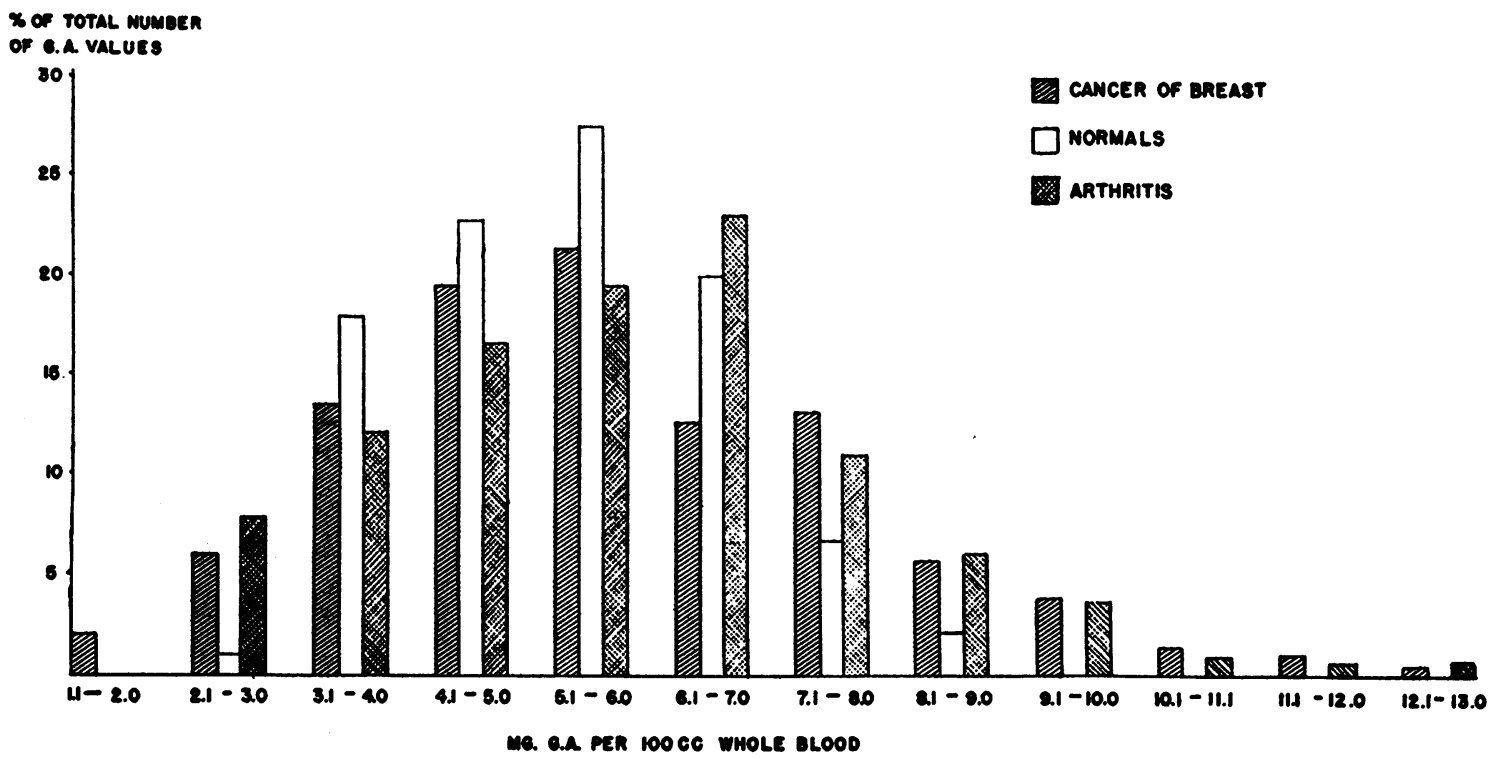

Fig. 3. Distribution of Glucuronic Acid (G.A.) Values in Normal Healthy Individuals (100), in Cancer Patients (128), and in Arthritic Subjects (44).

of the breast. In Table II are presented additional data on blood glucuronic acid in disease states. Values for blood $\beta$-glucuronidase activity obtained in these same patients have been included.

\section{DISCUSSION}

It would appear that the majority of human blood glucuronic acid values range from 4 to $8 \mathrm{mg}$. per $100 \mathrm{cc}$., averaging $6 \mathrm{mg}$. per $100 \mathrm{cc}$. These values are higher than those reported by Laing and Anderson (13) (2.3-6.6 mg. per $100 \mathrm{cc}$., average 4.0 ), and include values lower than those obtained by Ratish and Bullowa (10) (6.8-9.2 mg. per 100 cc., average 7.5). Ratish and Bullowa state that results out of accuracy range are obtained with amounts of glucurone $5 \mathrm{mg}$. or less per $100 \mathrm{cc}$. The procedure of Laing and Anderson is similar to that of Ratish and Bullowa, with the greater possibility of incomplete color development due to a shorter heating period and the omission of alcohol in the process of pigment extraction. However, under the experimental conditions described here there is a greater opportunity for maximum pigment formation (one hour heating) and

TABLE II

Concentration of blood glucuronic acid and serum $\beta$-glucuronidase in health and disease

\begin{tabular}{|c|c|c|c|c|c|c|c|c|}
\hline \multirow[b]{2}{*}{ Diagnosis } & \multicolumn{4}{|c|}{ Glucuronic acid } & \multicolumn{4}{|c|}{$\beta$-Glucuronidase } \\
\hline & $\begin{array}{l}\text { Number of } \\
\text { patients }\end{array}$ & $\begin{array}{l}\text { Number of } \\
\text { determina- } \\
\text { tions }\end{array}$ & $\begin{array}{c}\text { Range of } \\
\text { values }\end{array}$ & $\begin{array}{c}\text { Average } \\
\text { value } \\
(m g . / 100 ~ c c . \\
\text { blood })\end{array}$ & $\begin{array}{c}\text { Number of } \\
\text { patients }\end{array}$ & $\begin{array}{l}\text { Number of } \\
\text { determina- } \\
\text { tions }\end{array}$ & $\begin{array}{l}\text { Range of } \\
\text { values }\end{array}$ & $\begin{array}{c}\text { Average value } \\
\text { (units } / 100 \text { cc. } \\
\text { serum) }\end{array}$ \\
\hline $\begin{array}{l}\text { No disease } \\
\text { Cancer (all types) } \\
\text { Cancer of breast } \\
\text { Cancer of cervix } \\
\text { Cancer of lung } \\
\text { Cancer of intestinal tract } \\
\text { Heart disease } \\
\text { Diabetes } \\
\text { Pregnancy } \\
\text { Toxemia of pregnancy } \\
\text { Arthritis (male) } \\
\text { Arthritis (female) }\end{array}$ & $\begin{array}{r}100 \\
128 \\
57 \\
5 \\
5 \\
6 \\
33 \\
5 \\
15 \\
6 \\
7 \\
37\end{array}$ & $\begin{array}{r}104 \\
156 \\
90 \\
13 \\
6 \\
16 \\
36 \\
11 \\
15 \\
6 \\
94 \\
191\end{array}$ & $\begin{array}{l}3.0-9.0 \\
3.0-19.4 \\
3.0-9.0 \\
4.4-8.4 \\
4.7-8.1 \\
3.7-14.0 \\
1.8-10.1 \\
2.3-8.1 \\
4.0-9.7 \\
5.3-9.5 \\
2.2-11.3 \\
2.0-12.0\end{array}$ & $\begin{array}{l}6.1 \\
7.5 \\
5.9 \\
6.7 \\
6.4 \\
6.9 \\
5.1 \\
5.1 \\
6.2 \\
6.8 \\
5.5 \\
5.8\end{array}$ & $\begin{array}{r}230 \\
143 \\
57 \\
19 \\
11 \\
20 \\
40 \\
5 \\
15 \\
5 \\
7 \\
39\end{array}$ & $\begin{array}{r}500 \\
428 \\
280 \\
27 \\
16 \\
39 \\
43 \\
21 \\
15 \\
5 \\
91 \\
208\end{array}$ & $\begin{array}{r}41-1285 \\
100-2340 \\
114-2340 \\
206-1210 \\
329-1360 \\
191-1945 \\
141-1093 \\
181-1320 \\
262-1395 \\
675-1560 \\
247-1090 \\
141-1395\end{array}$ & $\begin{array}{r}389 \\
587 \\
638 \\
544 \\
718 \\
514 \\
439 \\
447 \\
798 \\
1151 \\
552 \\
468\end{array}$ \\
\hline
\end{tabular}


for efficient extraction of the resulting pigment (solution of the pigment first in alcohol and subsequent extraction with toluene). We have not encountered any interference of urinary pigment mentioned by Maughan and associates (11) in the determination of glucuronic acid in the urine.

From an inspection of the light absorption spectra of the toluene extract obtained by processing human blood and urine, it seems that under ordinary circumstances only the pigment produced by the glucuronic acid-naphthoresorcinol reaction is present and has an absorption maximum at 570 $580 \mathrm{~m} \mu$. Pure glucurone solutions yield toluene solutions of pigment absorbing at $570 \mathrm{~m} \mu$. Ratish and Bullowa have shown that interference due to pentoses and glucose is negligible. Maughan and associates have likewise found the naphthoresorcinol reaction to be negative for many body metabolites. As mentioned before, galacturonic acid reacts with naphthoresorcinol.

The experience in this laboratory indicates an error in the recovery experiments of approximately 8 per cent. Much of this is due to the fact that analyses are rejected only if duplicate tubes differ by more than 2 galvanometer divisions in their readings of transmittance. This is the outside limit within which duplicate determinations of most other substances, e.g., blood glucose, will agree when color measurements are made with the Evelyn photoelectric colorimeter. Accordingly, greater accuracy can be obtained either by the use of triplicate determinations, or by the development of conditions which will increase still further the optical density of the final toluene extract. For our purposes, the present procedure was found satisfactory.

The comparison of glucuronic acid values in the blood of healthy and diseased individuals is incomplete. It is clear, however, that in certain cases of arthritis and cancer there is a tendency toward abnormal values out of the range of the normal subjects studied. No clear correlations can be made between serum $\beta$-glucuronidase activity and blood glucuronic acid in the diseases studied.

\section{SECTION II. GLUCURONIC ACID TOLERANCE CURVES IN HUMANS}

When studying the metabolism of any substance, it has been found useful to obtain some measure of the degree of utilization of the substance by the body. Accordingly, it was considered worthwhile to develop a tolerance test for glucuronic acid in humans in order to study the utilization of glucuronic acid and factors which may influence its metabolism.

Employing the method for blood glucuronic acid described in the first section of this paper, blood levels of glucuronic acid were determined before, and at intervals after, oral administration of glucuronolactone. It was found that only a small proportion of this substance was excreted in the urine.

Glucuronic acid tolerance curves were then obtained on 17 normal subjects, on 12 patients with arthritis and on 10 patients with various types of cancer. A description of the technique for per-

TABLE III

Urinary excretion of glucuronic acid before, during and after performance of the glucurone tolerance test

The excretion of glucuronic acid in a single subject on five consecutive days gave the following 24 hour values: $0.64,0.63,0.58,0.75,0.31$ grams.

\begin{tabular}{|c|c|c|c|c|}
\hline \multirow[b]{2}{*}{ Patient } & \multirow[b]{2}{*}{ Clinical diagnosis } & \multicolumn{3}{|c|}{$\begin{array}{l}\text { Urinary glucuronic acid } \\
\text { (grams } / 24 \text { hours) }\end{array}$} \\
\hline & & $\begin{array}{c}\text { Day } \\
\text { prior to } \\
\text { tolerance } \\
\text { test }\end{array}$ & $\begin{array}{c}\text { Day of } \\
\text { tolerance } \\
\text { test }\end{array}$ & $\begin{array}{c}\text { Day } \\
\text { after } \\
\text { tolerance } \\
\text { test }\end{array}$ \\
\hline $\begin{array}{l}\text { L. I. } \\
\text { O. B. } \\
\text { C. F. } \\
\text { O. S. } \\
\text { E. C. } \\
\text { K. H. } \\
\text { K. J. } \\
\text { M. E. } \\
\text { G. A. }\end{array}$ & $\begin{array}{l}\text { Rheumatoid arthritis } \\
\text { Carcinoma of lung } \\
\text { Carcinoma of bladder } \\
\text { Toxemia of pregnancy } \\
\text { Rheumatoid arthritis } \\
\text { Myasthenia gravis, arthritis } \\
\text { Rheumatoid arthritis } \\
\text { Carcinoma of breast } \\
\text { Arthritis }\end{array}$ & $\begin{array}{l}0.82 \\
0.50 \\
0.67 \\
0.83 \\
0.23 \\
0.34 \\
0.65 \\
\overline{0.28}\end{array}$ & $\begin{array}{l}1.62 \\
0.39 \\
0.55 \\
0.53 \\
0.56 \\
1.02 \\
1.44 \\
0.91 \\
0.72\end{array}$ & $\begin{array}{l}0.49 \\
0.39 \\
1.04 \\
0.64 \\
0.32 \\
0.44 \\
0.65 \\
0.52 \\
0.23\end{array}$ \\
\hline
\end{tabular}

forming the glucuronic acid tolerance curve and the results obtained on various human subjects are presented in this section.

The glucuronic acid tolerance curve. Five cc. of venous blood are taken from the antecubital vein from a fasting subject immediately before the oral ingestion of 5 grams of glucurone ${ }^{5}$ dissolved in $100 \mathrm{cc}$. $\mathrm{H}_{2} \mathrm{O}$. The same amount of blood is drawn at 30 minutes, and one, two, three, six and 24 hour intervals thereafter. The blood is collected in an oxalated test tube to prevent clotting. Folin-Wu filtrates are then prepared from $2 \mathrm{cc}$. of this blood and

5 Glucurone is an abbreviation for glucuronolactone. In the body glucurone is undoubtedly in equilibrium with glucuronic acid, thus: glucuronolactone $+\mathrm{H}_{2} \mathrm{O} \rightleftarrows$ glucuronic acid. Pure glucurone was supplied through the courtesy of the Commercial Solvents Corporation, New York. 


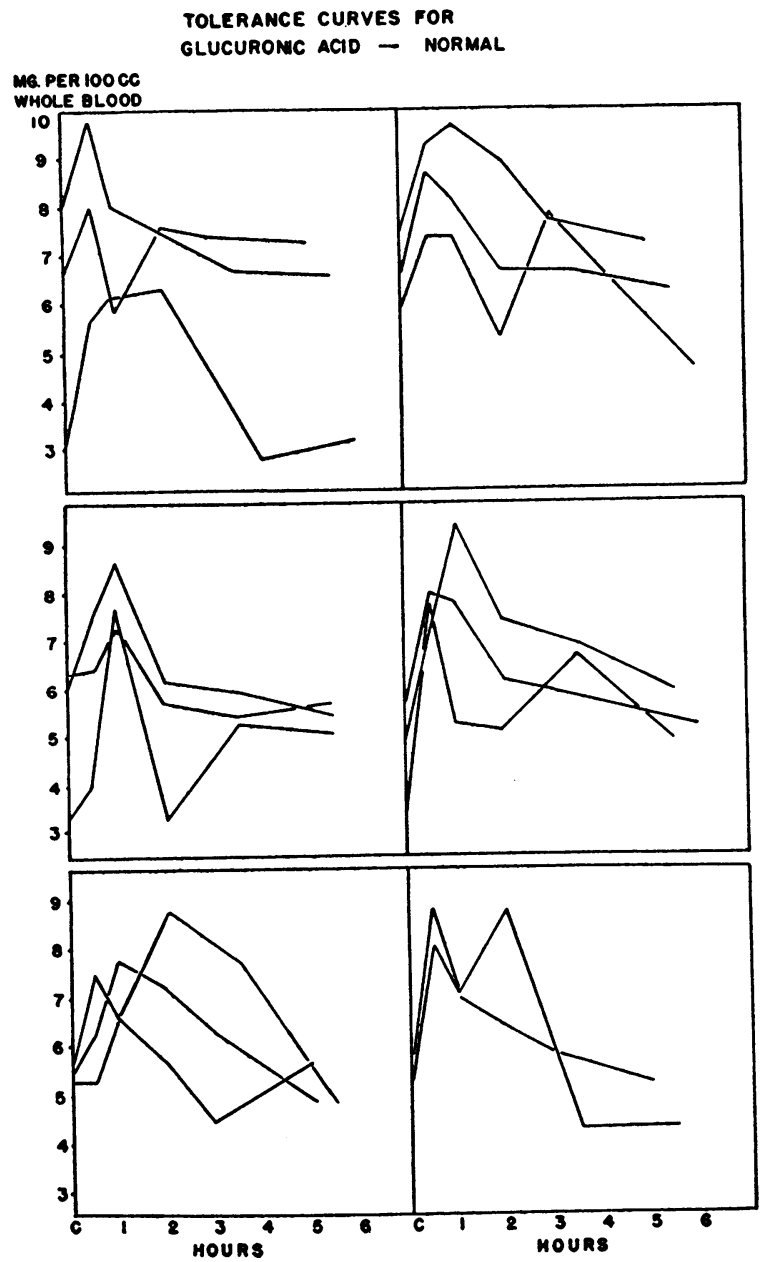

Fig. 4. Glucuronic Acid Tolerance Tests in Normal Healthy Indrviduals

the glucuronic acid determined as described. These values are then related to time, as illustrated in Figures 4 and 5. These represent, respectively, individual tolerance curves and a composite graph, based on the individual data.

In some of these experiments 24 hour urine collections were made on the day before, the day of, and the day after performing the glucurone tolerance test. These data appear in Table III. For the present, an abnormal curve is defined as one which either (a) fails to show an elevation in blood glucuronic acid after glucurone ingestion (flat curve); (b) shows the glucuronic acid level, after reaching a peak, failing to fall by six hours to the pre-ingestion level (retenton curve); or (c) shows a fall of glucuronic acid concentration at six hours to a value much lower than the fasting level (declining curve).

In all of the tolerance tests, $\beta$-glucuronidase activity of blood serum was determined simultaneously (14) and a typical result, illustrating the behavior of blood glucuronic acid and $\beta$-glucuronidase activity, is shown in Figure 6.
RESULTS

All of the normal subjects (Figure 4) exhibited an elevation in blood glucuronic acid following the ingestion of 5 grams of glucurone which appeared within 30 to 60 minutes and which persisted for as long as four hours. However, by six hours, in the majority of cases, the blood glucuronic acid levels had returned to the pre-ingestion level. In five subjects, two peaks in the curve were noted. A composite curve of these data is shown in Figure 5 .

Arthritis (Figure 7). Five of 12 arthritic patients showed abnormal curves in which the level at six hours was as high as or higher than the peak elevation; the curves in the remainder appeared essentially normal.

Cancer (Figure 8). Four patients with carcinoma of the rectum exhibited abnormal, flat or retention curves. Two subjects with cancer of the lung, and one with cancer of the thyroid showed accentuated declines in their blood glucuronic acid levels after the peak had been reached. One patient with cancer of the lung at six hours still showed an elevation in blood glucuronic acid.

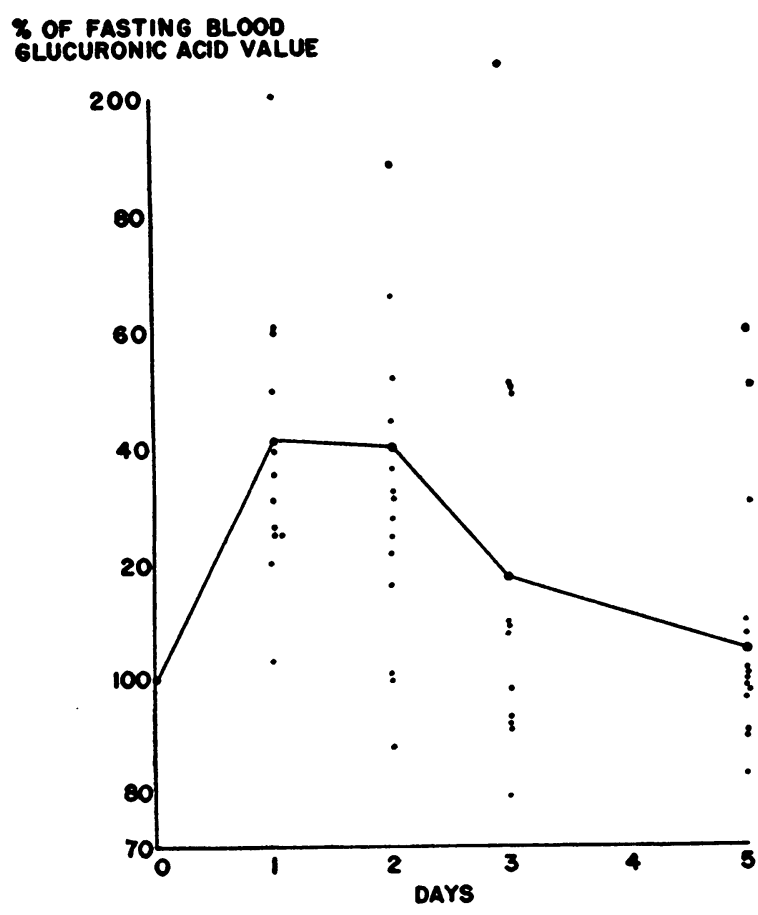

Fig. 5. A Composite Curve of the normal Glucuronic Acid Tolerance Tests 


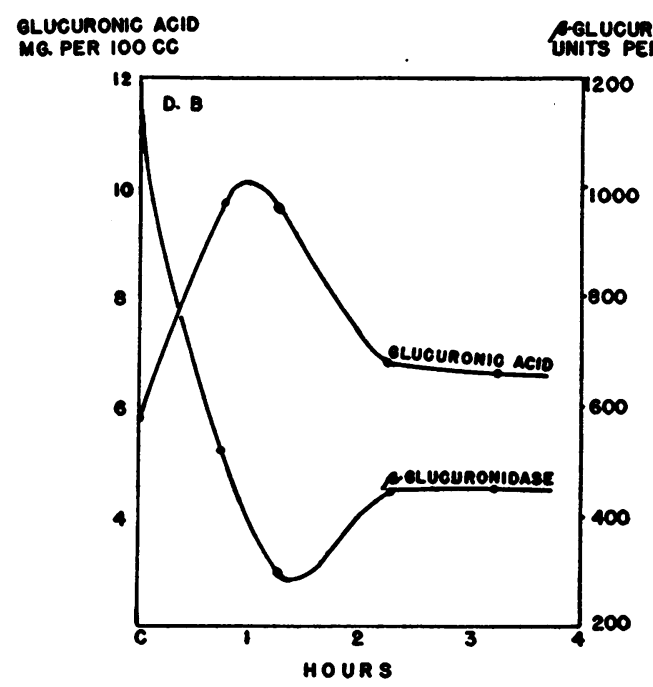

Fig. 6. Interrelation of Blood Glucuronic Acid AND $\beta$-GLUCURONIDASE AFTER INGESTION OF GLUCURONIC ACID

Three of the cancer subjects had fasting levels of glucuronic acid above $8 \mathrm{mg}$. per $100 \mathrm{cc}$. of blood.

Relation between blood glucuronic acid and serum $\beta$-glucuronidase. Figure 6 shows the blood $\beta$-glucuronidase activity being reduced markedly
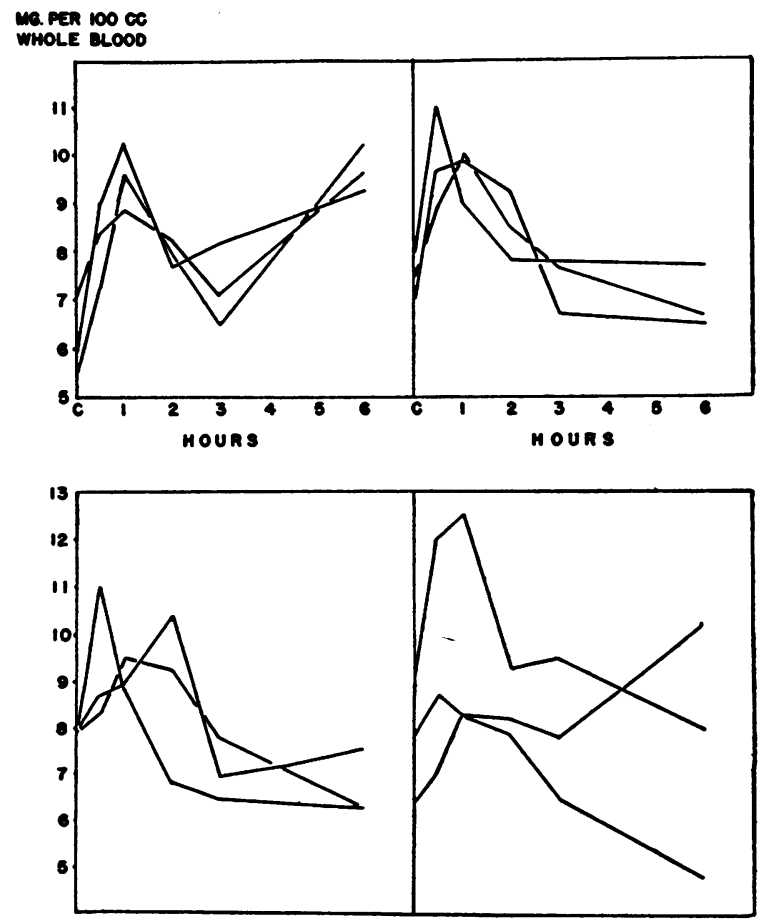

Fig. 7. Glucuronic Acid Tolerance Tests in Arthritis at the same time when the blood glucuronic acid increases. After two hours, the values for both level off, that for glucuronic acid returns towards the pre-ingestion value and that for $\beta$-glucuronidase tends to remain far below the initial one. In all subjects studied, healthy as well as diseased, the blood $\beta$-glucuronidase was reduced following glucuronolactone ingestion. The extent of this effect and its persistence was variable, usually bearing some relationship to the fasting blood $\beta$-glucuronidase. Thus, the decline was most pro-
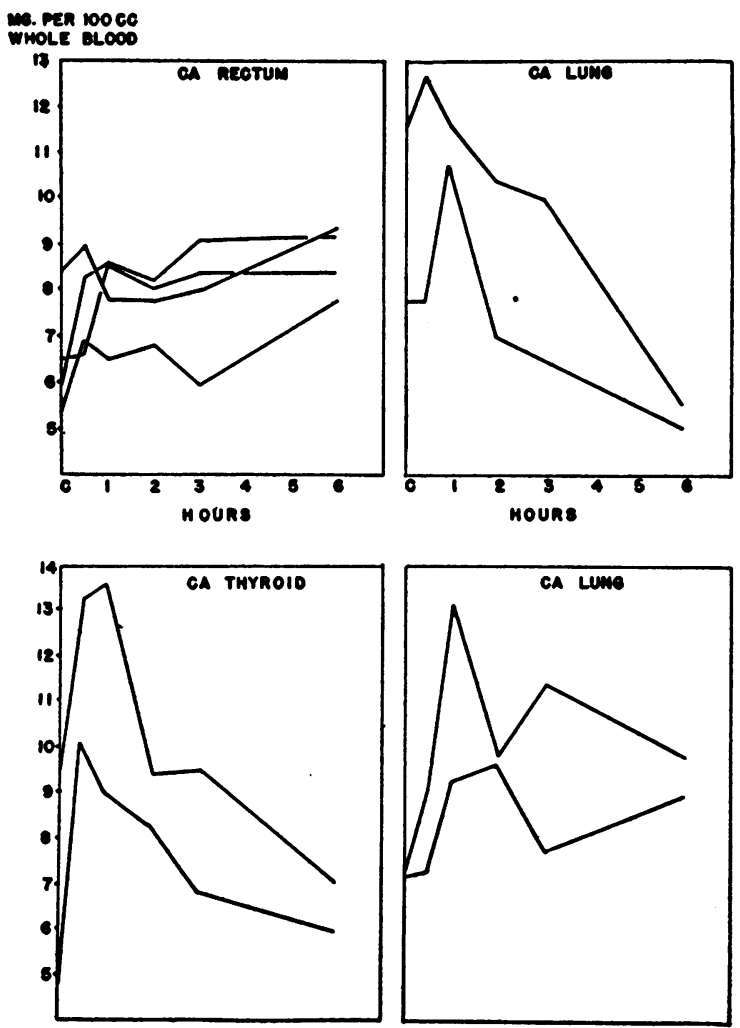

Fig. 8. Glucuronic Acid Tolerance Tests in Cancer Patients

nounced in subjects exhibiting initial $\beta$-glucuronidase activities above 500 units per $100 \mathrm{cc}$.

\section{DISCUSSION}

The following possibilities suggest themselves to explain the reduction of $\beta$-glucuronidase activity in blood in the presence of an increased blood glucuronic acid : 1) glucuronic acid may be inhibiting the activity of the enzyme, 2) glucuronic acid may cause a shift of the enzyme to the formed elements of the blood (in which case the serum en- 
TABLE IV

Effect of the presence of added glucuronic acid on $\beta$-glucuronidase activity of serum and plasma

The serum employed was prepared from blood taken from patients with cancer of the breast undergoing hormonal therapy which explains the higher $\beta$-glucuronidase activity observed as compared to the plasma enzyme activities (normal healthy subjects).

\begin{tabular}{|c|c|}
\hline $\begin{array}{c}\text { p-Glucuronidase activity } \\
\text { no glucuronic acid } \\
\text { added }\end{array}$ & $\begin{array}{c}\text { Units } / 100 \mathrm{cc} . \\
\text { glucuronic acid } \\
\text { added }(4 \mathrm{mg} .1100 \mathrm{cc} .)\end{array}$ \\
\hline \multicolumn{2}{|l|}{$\begin{array}{r}1690 \\
930 \\
673 \\
683 \\
930 \\
943 \\
900\end{array}$} \\
\hline \multicolumn{2}{|c|}{ Plasma separated from whole blood } \\
\hline $\begin{array}{l}447 \\
460 \\
504 \\
676\end{array}$ & $\begin{array}{l}435 \\
433 \\
504 \\
714\end{array}$ \\
\hline
\end{tabular}

zyme would be depleted) or 3) the glucuronic acid may cause blood $\beta$-glucuronidase to be removed from the blood for some as yet unknown purpose. As indicated in Table IV, there is no inhibition of serum $\beta$-glucuronidase in experiments where glucuronic acid is added in vitro in amounts corresponding to the highest concentrations of this substance observed in our tolerance curves. It is also clear that glucuronic acid added to whole blood does not result in a shift of $\beta$-glucuronidase from the plasma to the cells.

Since little change is found in the amounts of glucurone excreted in the urine during and after the tolerance test, there seems to be little doubt that the glucurone administered orally is utilized by the human subject. It remains to be determined which organ(s) take up this glucuronic acid and in which processes of metabolism the glucurone participates.

A pattern of glucuronic acid curves is evolving with three distinct types of curves. Some of these curves appear to be characteristic of certain types of cancer and to a much lesser extent arthritis and other chronic diseases (15).

\section{SECTION III. OBSERVATIONS IN PATIENTS RECEIVING ANTI-ARTHRITIC AND ANTI- TUMORAL AGENTS}

\section{Arthritis}

Four patients with an established diagnosis of rheumatoid arthritis were treated with ACTH, cortisone and glucurone and were studied from 70 to 150 days. All of these subjects at one or more periods in the study exhibited sudden and marked elevations in serum $\beta$-glucuronidase and in three, the blood glucuronic acid levels fluctuated markedly. The behavior of these two blood constituents in one of these patients whose arthritis was difficult to control is illustrated in Figure 9. In normal healthy subjects, blood glucuronic acid and serum $\beta$-glucuronidase levels are considerably more constant.

\section{Cancer of the breast}

A. Methylandrostenediol. Thirteen patients with metastatic cancer of the breast were treated for two to 18 months with methylandrostenediol, a weakly-virilizing protein anabolic steroid (16). In three of these subjects, showing neither subjective nor objective clinical improvement, $\beta$-glucuronidase and glucuronic acid values showed no change during the course of therapy. In $10 \mathrm{pa}-$ tients with subjective improvement, including three with objective responses, the values of these blood constituents were abnormally high at one or more times during therapy. The behavior of blood glucuronic acid and serum $\beta$-glucuronidase levels is illustrated in one of these subjects in Figure 10. Clinically, there appeared to be a correlation of the increased levels of either one or both of these blood constituents with the improvement observed in the patient.

$B$. Stilbestrol. The administration of this hormone was found to increase the blood $\beta$-glucuronidase not only in women with cancer of the breast (17) but also in non-cancerous subjects (15). It had been found previously (18) that stilbestrol administered for 10 days of the post-partum period will prevent to a great extent the fall in serum $\beta$-glucuronidase which otherwise normally occurs following parturition. The resemblance of the effects of methylandrostenediol and stilbestrol upon the $\beta$-glucuronidase and the glucuronic acid of the blood is of interest from two points of view. First, it offers an avenue of approach to the development of chemical indices in the blood for evaluating the effect of chemo-therapeutic drugs in cancer of the breast and secondly, it suggests that in these subjects methylandrostenediol has a biochemical effect in common with stilbestrol. 


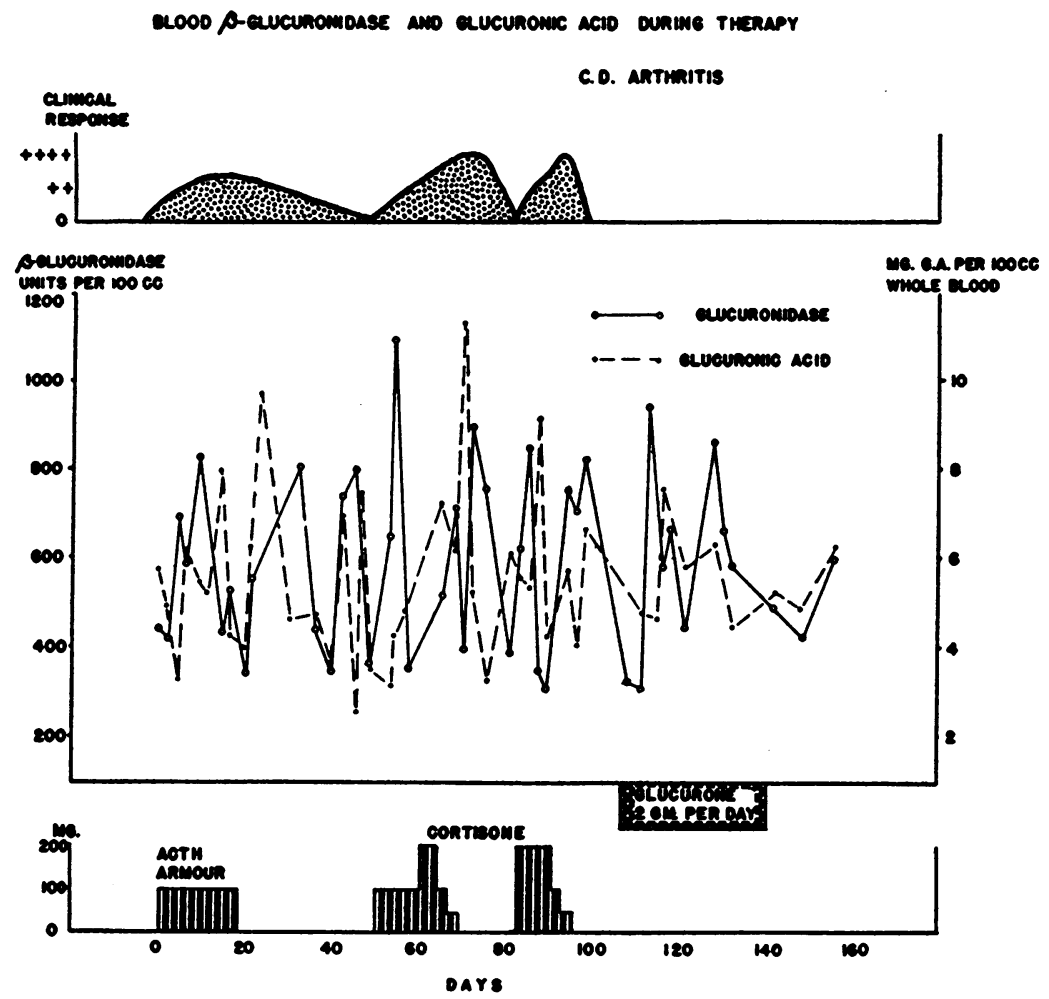

Fig. 9. Variations in the Blood Glucuronic Acid (G.A.) Concentration and in Serum $\beta$-Glucuronidase Activity in an Arthritic Pattent Receiving THERAPY

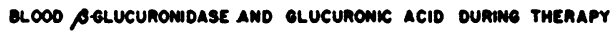

D.8. CANCER OF BREAST

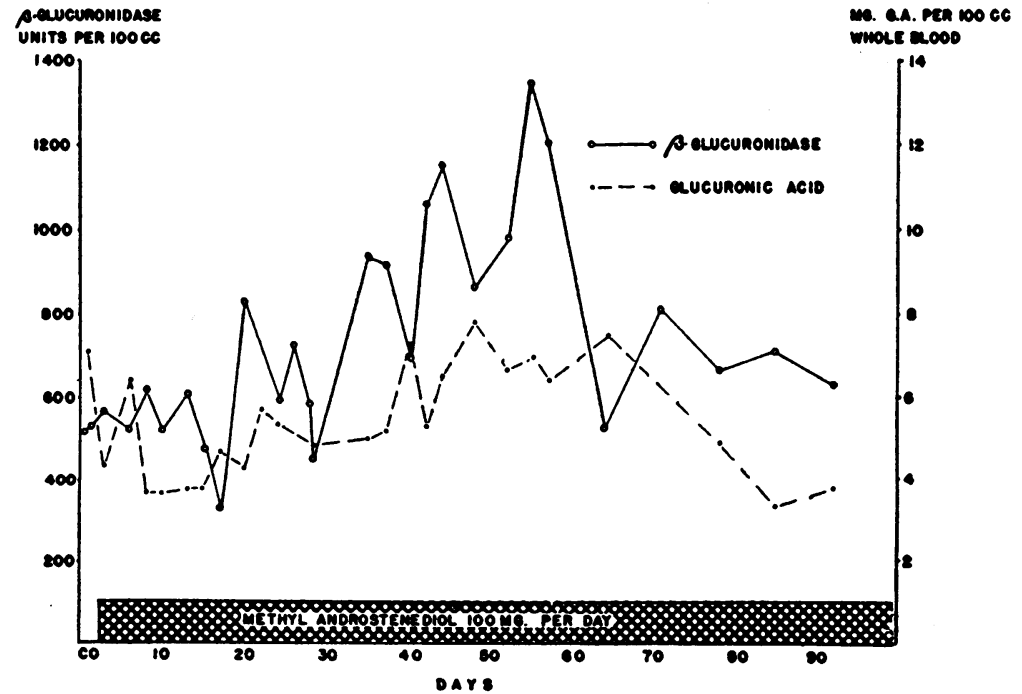

Fig. 10. The Efrect of Methylandrostenediol on Blood Glucuronic Concentration and Serum $\beta$-Glucuronidase Activity 


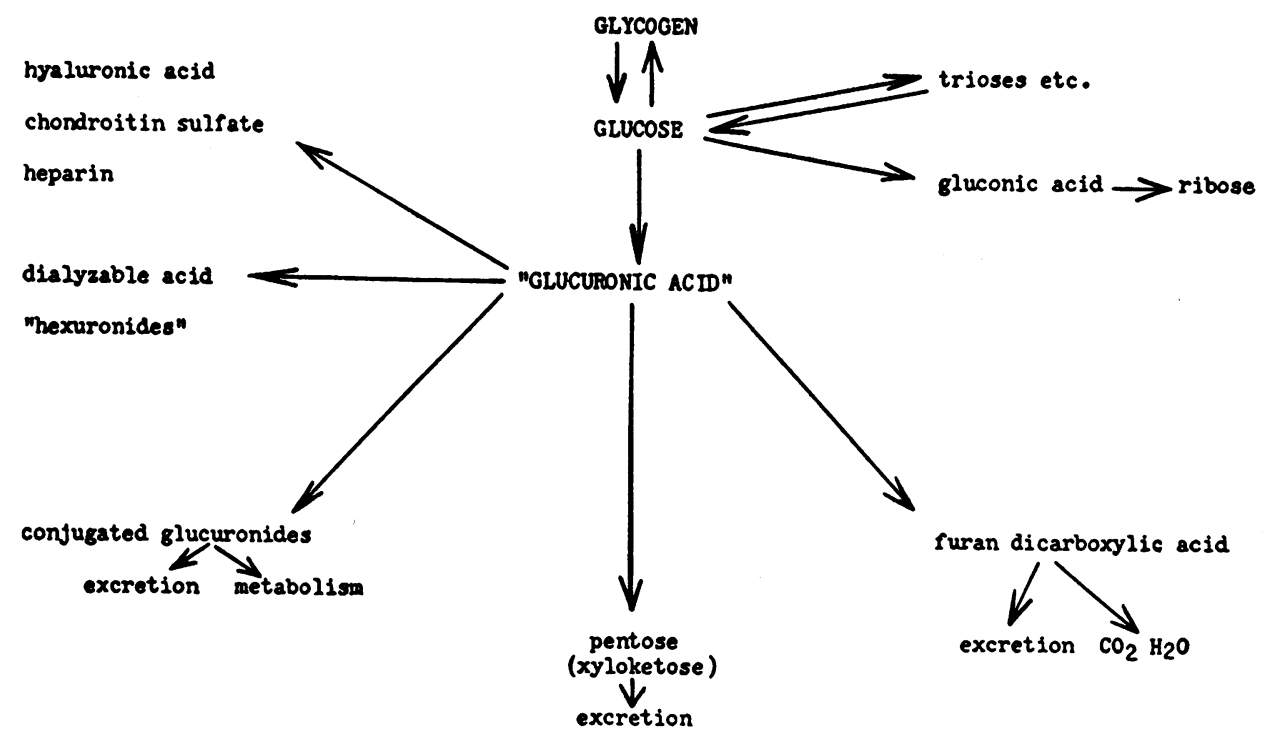

Fig. 11. A Tentative Scheme for Glucuronic Acid Metabolism

It remains to be established whether the phenomena observed with regard to glucuronic acid and glucuronidase in the blood of patients with arthritis or cancer under therapy are specific for these disorders or whether they may be the reflection of a fundamental systemic effect without specific significance.

\section{GENERAL DISCUSSION}

There are only a few known facts concerning the origin and fate of glucuronic acid in mammals.

Origin of glucuronic acid. It is generally believed that liver glycogen is the ultimate source of glucuronic acid. Quick (19), in 1926, showed that the administration of insulin to diabetic dogs greatly increased the output of glucuronic acid, while Kobayashi (20), in 1934, found low glycogen content in the livers of rabbits which had been given the glucuronidogenic drug, avertin. Later, Schmid (21) reported that the tolerance to menthol was much less in hibernating frogs whose liver glycogen had been depleted and Dziewiatkowski and Lewis (22) found a 50 per cent reduction in liver glycogen four hours after administering menthol to rats.

Direct evidence that glucose can be used for the synthesis of glucuronic acid in conjugated form was reported by Mosbach and King (23). After administering glucose labelled with $\mathrm{C}^{14}$ uniformly in all six carbons to guinea pigs which were simul- taneously given borneol, the glucuronic acid of the $\mathrm{Zn}$ bornyl glucuronide isolated from the urine was found to contain radioactive carbon, likewise uniformly distributed amongst its six carbon atoms.

On the other hand, administered glucuronic acid is not converted into glucose, since, to take one example, Quick (24) was unable to relieve insulin convulsions in mice by the administration of glucurone.

Fate of glucuronic acid. Glucuronic acid in amounts of 3 to 10 grams is almost completely metabolized by humans (24-26) and rabbits and dogs similarly metabolize glucuronic acid (27). Flaschenträger and colleagues (26) isolated furan dicarboxylic acid from the urine of healthy subjects who had received glucurone in amounts which indicated a 20 per cent conversion of the glucurone to this compound. The furan dicarboxylic acid itself is almost completely metabolized when given to humans.

Enklewitz and Lasker (25) gave glucurone to pentosuriacs, since they had seen increased pentosuria following the administration to these patients of glucuronidogenic drugs. Over 20 per cent of glucurone was apparently converted into the $l$-xyloketose which was identified. This effect was not seen following the administration of conjugated glucuronic acid.

Quick (24) first reported that dogs metabolized menthol and menthol glucuronide almost com- 
pletely, and borneol and its glucuronide to a great extent. Smith and Williams (28) demonstrated that the rabbit metabolized stilbestrol glucuronide. It therefore seems reasonable that the intact conjugated glucuronides may undergo metabolism.

Scheme of glucuronic acid metabolism. In the accompanying scheme (Figure 11) the facts detailed above have been related. The evidence for dialyzable acid hexuronides rests on observations we have made on the nature of tissue uronides which show clearly that the dialyzable uronide of tissue is of a molecular species lower than hyaluronic acid and higher than that of the simple conjugated glucuronides. In all the pathways postulated uncertainty is indicated as to the exact mechanism. Final conclusive proof that glucuronic acid behaves in the manner outlined must await definitive studies, possibly utilizing glucuronic acid labelled with $\mathrm{C}^{14}$.

Present results. In our studies, it has been found that glucuronic acid in 5 gram amounts given orally is almost completely utilized as judged by the urinary excretion of glucuronic acid.

Glucuronic acid tolerance curves. Of interest is the rapidity with which blood glucuronic acid levels, once elevated by oral glucuronic acid, decline to normal values. It would seem that the concentration of this substance is under homeostatic control by agencies which at present are unknown. The blood sugar and phosphorus remain unchanged during the course of glucuronic acid absorption and utilization. Accordingly, the postulated homeostatic mechanism is probably unrelated to glucose metabolism and may be related to formation of pentose and furan dicarboxylic acid.

Observations in arthritis and cancer. In certain patients, e.g., those with cancer of the rectum, there appears to be a definite retention of glucuronic acid in the blood, and in others (see Figure 8) there exists a tendency for a marked decline in blood glucuronic acid. In all patients, the serum glucuronidase declined after ingestion of glucuronic acid. On the basis of the present data, no explanation can be advanced for these phenomena, nor can these phenomena be considered peculiar only for cancer and arthritis.

The lability of glucuronic acid concentration in the blood of patients with rheumatoid arthritis is interesting. It is known that glucuronic acid compounds such as hyaluronic acid and chondroitin sulfate are important constituents of cartilage and the joint capsule. The present observations raise the question whether or not arthritis may be accompanied by a disorder of glucuronic acid metabolism.

The frequent elevations of glucuronic acid seen in the blood of patients with carcinoma of the breast receiving methylandrostenediol therapy is a new observation for which no explanation is proposed.

Finally, it is found that the continuation of study in this relatively new field of investigation may help in our attempts to understand the interrelationships in metabolism of the steroid hormones, glucuronic acid and $\beta$-glucuronidase.

\section{CONCLUSIONS}

1. A method for determining glucuronic acid in blood and urine has been developed by modifying existing procedures and by substituting toluene for ether in the extraction of the violet pigment produced in the naphthoresorcinol reaction. Toluene solutions of the pigment absorbed light maximally at $570-580 \mathrm{~m} \mu$. A linear relationship was found between the optical density of toluene extracts prepared from the reaction of naphthoresorcinol with glucuronic acid in the range of concentrations employed ( $5 \gamma$ to $40 \gamma$ ).

Values are reported for 100 normal individuals and in a number of arthritics and patients with cancer of the breast.

2. Glucuronic acid (glucurone) administered orally appears to be utilized inasmuch as little of it is excreted in the urine. In normal subjects, a peak in the blood glucuronic acid is found within 30-60 minutes after ingestion which may persist from one to four hours. By six hours afterwards the blood glucuronic acid returned to pre-ingestion levels.

3. In five out of 12 arthritics and seven of 10 patients with cancer, these glucuronic acid tolerance curves were abnormal. Some showed what appeared to be retention of glucuronic acid in the blood while others were characterized by an unusually marked fall in glucuronic acid after the peak concentration had been passed.

4 . Serum $\beta$-glucuronidase activity fell simultaneously with the rise in blood glucuronic acid seen in the glucuronic acid tolerance test. 
5. These findings have been discussed in relation to the known facts of glucuronic acid metabolism which have been received.

\section{REFERENCES}

1. Fishman, W. H., $\beta$-glucuronidase: its relation to the action of the estrogenic hormones. J. Biol. Chem., 1947, 169, 7.

2. Cohen, S. L., and Marrian, G. F., The isolation and identification of a combined form of oestriol in human pregnancy urine. Biochem. J., 1936, 30, 57.

3. Venning, E. M., and Browne, J. S. L., Isolation of a water-soluble pregnandiol complex from human pregnancy urine. Proc. Soc. Exper. Biol. \& Med., 1936, 34, 792.

4. Clark, W. G., Akawie, R. I., Pogrund, R. S., and Geissman, T. A., Conjugation of $l$-epinephrine in vivo. Abstracts of Communication of 18th International Physiological Congress, 1950, p. 159.

5. Peterman, E. A., Glucuronic acid deficiency in the rheumatic diseases. Journal Lancet, 1947, 67, 451.

6. Handler, P., and Perlzweig, W. A., Detoxication mechanisms. Ann. Rev. Biochem., 1945, 14, 617.

7. Bodansky, O., The metabolism of drugs and toxic substances. Ann. Rev. Biochem., 1948, 17, 303.

8. Bloch, $\mathrm{K}$., The metabolism of acetic acid in animal tissues. Physiol. Rev., 1947, 27, 574.

9. Young, L., The detoxication of carbocyclic compounds. Physiol. Rev., 1939, 19, 323.

10. Ratish, H. D., and Bullowa, J. G. M., Determination of glucuronic acid in biological media. Arch. Biochem., 1943, 2, 381.

11. Maughan, G. B., Evelyn, K. A., and Browne, J. S. L., A method for the quantitative estimation of glucuronic acid and conjugated glucuronides. J. Biol. Chem., 1938, 126, 567.

12. Deichmann, W. B., and Dierker, M., The spectrophotometric estimation of hexuronates (expressed as glucuronic acid) in plasma or serum. J. Biol. Chem., 1946, 163, 753.

13. Laing, G. H., and Anderson, D., Glucuronic acid. Method of determination and normal blood levels. Abstracts, Am. Chem. Soc., Division of Biological Chemistry, Detroit, 1950, p. 610.

14. Fishman, W. H., Springer, B., and Brunetti, R., Application of an improved glucuronidase assay method to the study of human blood beta-glucuronidase. J. Biol. Chem., 1948, 173, 449.

15. Fishman, W. H., Homburger, F., Kasdon, S. C., and Bonner, C. D., $\beta$-Glucuronidase alterations in human cervical and breast cancer. Cancer Research, 1951, 11, 248.

16. Homburger, F., Kasdon, S. C., and Fishman, W. H., Methylandrostenediol, a non-virilizing derivative of testosterone in metastatic cancer of the breast. Proc. Soc. Exper. Biol. \& Med., 1950, 74, 162.

17. Cohen, S. L., and Huseby, R. A., The effect of estrogen on the serum glucuronidase activity of patients with breast cancer. Cancer Research, 1951, $11,52$.

18. Fishman, W. H., Odell, L. D., Gill, J. E., and Christensen, R. A., II, The influence of stilbestrol on serum beta-glucuronidase in women following parturition. Am. J. Obst. \& Gynec., 1950, 59, 414.

19. Quick, A. J., On the origin of glucuronic acid in the organism. J. Biol. Chem., 1926, 70, 397.

20. Kobayashi, T., Experimentelle Untersuchungen über die Beziehungen zwischen Avertin und Leberfunktion. J. Biochem., 1934, 20, 405.

21. Schmid, F., Recherches sur le lieu de formation des conjugués glycuroniques dans l'organisme. Compt. rend. Soc. de biol., 1936, 123, 223.

22. Dziewiatkowski, D. D., and Lewis, H. B., Glucuronic acid synthesis and the glycogen content of the liver of the rat. J. Biol. Chem., 1944, 153, 49.

23. Mosbach, E. H., and King, C. G., Tracer studies of glucuronic acid biosynthesis. J. Biol. Chem., 1950, $185,491$.

24. Quick, A. J., Quantitative studies of $\beta$-oxidation. IV. The metabolism of conjugated glycuronic acids. J. Biol. Chem., 1928, 80, 535.

25. Enklewitz, M., and Lasker, M., The origin of $l$ xyloketose (urine pentose). J. Biol. Chem., 1935, $110,443$.

26. Flashenträger, B., Cagianut, B., and Meier, F., The formation of 2,5-furandicarboxylic acid from $d$-glucurone and $d$-galacturonic acid in man: a new metabolic pathway for carbohydrate. Helvet. chim. acta, 1945, 28, 1489.

27. Hürthle, R., Schicksal von Glykuronsäure und Galakturonsäure im Tierischen Organismus. Biochem. Ztschr., 1927, 181, 105.

28. Smith, A. E. W., and Williams, P. C., Urinary elimination of synthetic oestrogens and stilboestrol glucuronide in animals. Biochem. J., 1948, 42, 253. 